ORIGINAL ARTICLE

\title{
Concordance of microsatellite and mitochondrial DNA markers in detecting genetic population structure in the boring giant clam Tridacna crocea across the Indo-Malay Archipelago
}

\author{
Min Hui ${ }^{1,2}$, Agus Nuryanto ${ }^{3}$ \& Marc Kochzius ${ }^{4}$ \\ 1 Key Laboratory of Experimental Marine Biology, Institute of Oceanology, Chinese Academy of Sciences, Qingdao, China \\ 2 Biotechnology and Molecular Genetics, FB2, University of Bremen, Bremen, Germany \\ 3 Faculty of Biology, Jenderal Soedirman University, Purwokerto, Indonesia \\ 4 Marine Biology, Vrije Universiteit Brussel, Brussels, Belgium
}

\section{Keywords}

genetic diversity; microsatellites; mtDNA; population structure; South-East Asia.

\author{
Correspondence \\ Min Hui, Key Laboratory of Experimental \\ Marine Biology, Institute of Oceanology, \\ Chinese Academy of Sciences, 7 Nanhai \\ Road, Qingdao 266071, China. \\ E-mail:minhui@qdio.ac.cn
}

Accepted: 24 April 2016

doi: 10.1111/maec.12389

\begin{abstract}
Mitochondrial DNA (mtDNA) is a single, usually non-recombining locus, and often uniparentally inherited. Therefore, its ability to reveal recent gene flow among populations is usually questioned. In this study, the genetic population structure of 16 populations of Tridacna crocea $(n=366)$ from the Indo-Malay Archipelago (IMA) was examined with 10 microsatellite markers and compared to previous studies using mtDNA, in order to test if the revealed population structure was congruent between the two marker systems. The results showed that the genetic population structure revealed by the two marker systems was mostly congruent, with a high correlation between cytochrome c oxidase subunit I (COI) and microsatellites. The studied populations could be divided by both marker systems as follows: (i) Eastern Indian Ocean, (ii) Central IMA, and (iii) Western Pacific. Populations in the Central IMA showed high gene flow. However, populations in the Java Sea (Karimunjava, Pulau Seribu) were grouped into a separate cluster by mtDNA analysis, while this grouping was not detected by microsatellites. It was also noteworthy that there is obvious heterozygosity deficiency in most of the populations, which may be caused by null alleles, inbreeding or population expansion. Overall, these results indicate that the mitochondrial COI gene is applicable for population genetic analysis and precise recovery of connectivity patterns of giant clams. Therefore, the combination of mtDNA and nuclear DNA markers can lead to a more complete understanding of population genetics. Moreover, this study is expected to facilitate fully displaying the population genetic structure of giant clams combining with other researchers' results.
\end{abstract}

\section{Introduction}

Understanding the current distribution of and connectivity among populations of a species is important to illuminate historic and contemporary processes, as well as to provide baseline data for conservation. In recent years, different molecular marker systems have been developed for population genetic studies. Mitochondrial DNA (mtDNA) is widely used in this context and has many advantages. First, it usually evolves fast and thus shows high variability (Brown 1985). Second, due to the availability of universal primers, mtDNA fragments are also relatively easy to amplify and to sequence. Third, in phylogeographic studies, the maternal inheritance reduces 
the effective population size and shortens the amount of time required for lineage sorting to reveal phylogeographic patterns (Avise 2000). Lastly, many coral reef organisms, such as corals, sea anemones and giant clams harbor symbiotic algae (zooxanthellae) in their tissues, which needs to be considered during genome marker isolation and application. Therefore, it is much easier to apply mtDNA sequence markers than nuclear markers, as primers are available that do not amplify DNA from zooxanthellae. The population genetic structures of many marine species in the Indo-Malay Archipelago (IMA), one of the main marine evolutionary centers in the world, have been studied using mtDNA, such as giant clams (Tridacna crocea, DeBoer et al. 2008; Kochzius \& Nuryanto 2008; Tridacna maxima, Nuryanto \& Kochzius 2009), the blue starfish Linckia laevigata and its ectoparasite Thyca crystallina (Crandall et al. 2008a; Kochzius et al. 2009), gastropods (Nerita albicilla and Nerita plicata, Crandall et al. 2008b), the tiger prawn Penaeus monodon (Benzie et al. 2002), the anemonefish Amphiprion ocellaris (Nelson et al. 2000; Timm \& Kochzius 2008) and the scad mackerel Decapterus russelli (Perrin \& Borsa 2001).

However, mtDNA solely represents one locus, is usually maternally inherited and may be under strong selection (Bazin et al. 2006; Lee \& Edwards 2008; Zink \& Barrowclough 2008; Barrowclough \& Zink 2009; Edwards \& Bensch 2009). Therefore its ability to reveal recent gene flow among populations is questioned. Nuclear microsatellite markers, which are characterized as codominant and highly polymorphic, are expected to provide greater resolution for population genetic studies and are widely used in studies on genetic population structure of marine species, such as the shrimp Penaeus monodon (You et al. 2008) and the anemonefish Amphiprion ocellaris (Timm et al. 2012), as well as the butterflyfishes Chaetodon meyeri and Chaetodon ornatissimus (DiBattista et al. 2012). Many studies have also shown discordant genetic structures in the same species when applying nuclear DNA (nuDNA) and mtDNA (Toews \& Brelsford 2012). These findings indicate that caution should be taken when interpreting results from different molecular markers, and multi-locus studies should focus on revealing the driver of this discordance.

The boring giant clam, Tridacna crocea, which is distributed around the IMA, has a pelagic larval duration of around 10 days with the adults attached to the substrate (Lucas 1988), and therefore its dispersal capability is limited to some extent. Moreover, it lives in symbiosis with zooxanthellae. It is worth noting that all tridacnid species are listed in Appendix II of the Convention on International Trade in Endangered Species of Wild Fauna and Flora (CITES), allowing international trade only with appropriate export permits. Special concerns have been raised on the conservation of giant clams, indicating the need for urgent management based on a good understanding of the biology of these species. Population genetic data are already available for giant clams in some areas (Campbell et al. 1975; Benzie \& Williams 1992a,b, 1995, 1997; Macranas et al. 1992; Kittiwattanawong 1997; Yu et al. 2000; Kittiwattanawong et al. 2001; Laurent et al. 2002; Juinio-Meñez et al. 2003; Kochzius \& Nuryanto 2008; Nuryanto \& Kochzius 2009), but only one study has utilized microsatellites (DeBoer et al. 2014).

In this study, dense sampling was conducted in Central Indonesia (Borneo and Sulawesi), which was complementary to the study by DeBoer et al. (2014). The aims of this study were (i) to investigate the genetic population structure of $T$. crocea in the whole IMA by using microsatellites (DeBoer \& Barber 2010; Hui et al. 2011), and (ii) to compare the results with a previous investigation utilizing the mitochondrial COI gene (Kochzius \& Nuryanto 2008), in order to assess if the revealed genetic population structure is congruent between the two marker systems.

\section{Material and Methods}

\section{Sample collection}

Small pieces of mantle tissue were collected from 366 specimens of Tridacna crocea from 16 sites across the IMA by SCUBA diving (Table 1; Fig. 1). Tissue samples were preserved in $96 \%$ ethanol.

\section{DNA extraction, PCR amplification and fragment analysis}

Genomic DNA was extracted using the Chelex method (Walsh et al. 1991). The population structure was investigated with 10 polymorphic microsatellite markers (DeBoer \& Barber 2010; Hui et al. 2011; Table 2), which were labelled with 6-Fluorescein amidite or Hexachloro fluorescein. The PCRs were performed in a volume of $15 \mu \mathrm{l}$, containing $1 \times$ PCR buffer, $0.5 \mathrm{U}$ Taq polymerase (Takara), $1.5 \mathrm{mM}$ of $\mathrm{Mg}^{2+}, 200 \mu \mathrm{M}$ of each deoxy-ribonucleotide triphosphate, $0.2 \mu \mathrm{M}$ of each primer and about 40 ng of genomic DNA. The thermoprofile for all loci was as follows: an initial denaturation of $95{ }^{\circ} \mathrm{C}$ for $5 \mathrm{~min}$; $95{ }^{\circ} \mathrm{C}$ for $30 \mathrm{~s}$, locus-specific annealing temperature (Table 2) for $45 \mathrm{~s}, 72{ }^{\circ} \mathrm{C}$ for $45 \mathrm{~s}$ repeated 35 times, and ending with $72{ }^{\circ} \mathrm{C}$ for $5 \mathrm{~min}$. The fragment analysis was conducted with an ABI 3730 Automated Sequencer (Applied Biosystems) using the Liz size standard. The lengths of the fragments were analysed using the software GENEMARKER v. 1.91 (SoftGenetics, LLC). 
Table 1. Variation in microsatellite loci of 16 Tridacna crocea populations in the Indo-Malay Archipelago.

\begin{tabular}{|c|c|c|c|c|c|c|c|c|c|c|c|c|c|}
\hline \multirow[b]{2}{*}{ site } & \multirow[b]{2}{*}{ abbreviation } & \multirow{2}{*}{$n$} & \multicolumn{10}{|l|}{ locus } & \multirow{2}{*}{ mean } \\
\hline & & & TC1 & TC3 & TC5 & TC6 & TC8 & Tc059 & Tc074 & Tc092 & Tc160 & Tc161 & \\
\hline Padang & $\mathrm{Pa}$ & 7 & & & & & & & & & & & \\
\hline $\mathrm{N}_{\mathrm{a}}$ & & & 3 & 3 & 5 & 7 & 4 & 3 & 3 & 4 & 3 & 5 & 4 \\
\hline $\mathrm{H}_{\mathrm{o}}$ & & & 0.429 & 1.000 & 1.000 & 0.857 & 0.333 & 0.333 & 0.000 & 0.667 & 0.333 & 0.667 & 0.562 \\
\hline $\mathrm{H}_{\mathrm{e}}$ & & & 0.582 & 0.625 & 0.778 & 0.827 & 0.722 & 0.611 & 0.667 & 0.667 & 0.500 & 0.778 & 0.676 \\
\hline$P$ & & & 0.0722 & 1.0000 & 1.0000 & 0.0830 & 0.0663 & 0.1984 & 0.0667 & 0.6083 & 0.1945 & 0.1950 & \\
\hline Pulau Seribu & PS & 17 & & & & & & & & & & & \\
\hline $\mathrm{N}_{\mathrm{a}}$ & & & 5 & 14 & 15 & 16 & 13 & 9 & 10 & 17 & 9 & 14 & 12.2 \\
\hline $\mathrm{H}_{\circ}$ & & & 0.167 & 0.625 & 0.882 & 0.529 & 0.364 & 1.000 & 0.765 & 0.588 & 0.647 & 0.824 & 0.639 \\
\hline $\mathrm{H}_{\mathrm{e}}$ & & & 0.764 & 0.904 & 0.913 & 0.905 & 0.913 & 0.834 & 0.848 & 0.907 & 0.846 & 0.901 & 0.874 \\
\hline$P$ & & & 0.0007 & 0.0047 & 0.0031 & 0.0000 & 0.0000 & 0.0177 & 0.2608 & 0.0000 & 0.0560 & 0.1482 & \\
\hline Karimunjava & $\mathrm{Ka}$ & 14 & & & & & & & & & & & \\
\hline $\mathrm{N}_{\mathrm{a}}$ & & & 9 & 8 & 13 & 18 & 8 & 7 & 9 & 11 & 7 & 11 & 10.1 \\
\hline $\mathrm{H}_{\circ}$ & & & 0.231 & 0.636 & 0.583 & 0.692 & 0.571 & 0.750 & 0.583 & 0.600 & 0.545 & 0.900 & 0.609 \\
\hline $\mathrm{H}_{\mathrm{e}}$ & & & 0.867 & 0.810 & 0.865 & 0.929 & 0.857 & 0.778 & 0.816 & 0.875 & 0.831 & 0.885 & 0.851 \\
\hline $\mathrm{P}$ & & & 0.0000 & 0.0213 & 0.0006 & 0.0079 & 0.0418 & 0.1452 & 0.0068 & 0.0147 & 0.0462 & 0.7049 & \\
\hline Komodo & Ko & 27 & & & & & & & & & & & \\
\hline $\mathrm{N}_{\mathrm{a}}$ & & & 16 & 11 & 19 & 27 & 18 & 10 & 14 & 24 & 12 & 13 & 16.4 \\
\hline $\mathrm{H}_{\mathrm{o}}$ & & & 0.091 & 0.542 & 0.731 & 0.556 & 0.481 & 0.778 & 0.667 & 0.769 & 0.815 & 0.815 & 0.624 \\
\hline $\mathrm{H}_{\mathrm{e}}$ & & & 0.897 & 0.841 & 0.920 & 0.954 & 0.914 & 0.802 & 0.894 & 0.933 & 0.885 & 0.901 & 0.894 \\
\hline$P$ & & & 0.0000 & 0.0000 & 0.0032 & 0.0000 & 0.0000 & 0.1031 & 0.0002 & 0.0000 & 0.3952 & 0.1325 & \\
\hline Kupang & $\mathrm{Ku}$ & 9 & & & & & & & & & & & \\
\hline $\mathrm{N}_{\mathrm{a}}$ & & & 9 & 11 & 9 & 12 & 10 & 7 & 10 & 12 & 7 & 8 & 9.5 \\
\hline $\mathrm{H}_{\mathrm{o}}$ & & & 0.429 & 0.625 & 1.000 & 0.444 & 0.444 & 0.889 & 0.667 & 0.667 & 0.889 & 0.778 & 0.683 \\
\hline $\mathrm{H}_{\mathrm{e}}$ & & & 0.867 & 0.883 & 0.858 & 0.907 & 0.833 & 0.772 & 0.858 & 0.895 & 0.846 & 0.815 & 0.853 \\
\hline$P$ & & & 0.0000 & 0.0008 & 1.0000 & 0.0000 & 0.0000 & 0.4547 & 0.1068 & 0.0051 & 0.8615 & 0.1074 & \\
\hline Spermonde & Sp & 49 & 49 & & & & & & & & & & \\
\hline $\mathrm{N}_{\mathrm{a}}$ & & & 21 & 14 & 22 & 31 & 26 & 12 & 16 & 25 & 11 & 18 & 19.6 \\
\hline $\mathrm{H}_{\circ}$ & & & 0.118 & 0.653 & 0.625 & 0.510 & 0.487 & 0.776 & 0.652 & 0.326 & 0.625 & 0.958 & 0.573 \\
\hline $\mathrm{H}_{\mathrm{e}}$ & & & 0.939 & 0.911 & 0.928 & 0.937 & 0.937 & 0.832 & 0.886 & 0.945 & 0.900 & 0.920 & 0.913 \\
\hline $\mathrm{P}$ & & & 0.0000 & 0.0000 & 0.0027 & 0.0000 & 0.0000 & 0.0199 & 0.0025 & 0.0000 & 0.0000 & 0.8890 & \\
\hline Bira & $\mathrm{Bi}$ & 13 & & & & & & & & & & & \\
\hline $\mathrm{N}_{a}$ & & & 6 & 12 & 15 & 15 & 11 & 7 & 11 & 11 & 10 & 12 & 11 \\
\hline $\mathrm{H}_{\mathrm{o}}$ & & & 0.000 & 0.750 & 0.923 & 0.462 & 0.273 & 0.818 & 0.583 & 0.444 & 0.700 & 0.500 & 0.545 \\
\hline $\mathrm{H}_{\mathrm{e}}$ & & & 0.833 & 0.892 & 0.908 & 0.923 & 0.888 & 0.781 & 0.882 & 0.901 & 0.840 & 0.889 & 0.874 \\
\hline$P$ & & & 0.0002 & 0.1006 & 0.0456 & 0.0000 & 0.0000 & 0.2662 & 0.0000 & 0.0000 & 0.0982 & 0.0000 & \\
\hline $\begin{array}{l}\text { Sembilan } \\
\text { Islands }\end{array}$ & $\mathrm{Se}$ & 30 & & & & & & & & & & & \\
\hline $\mathrm{Na}_{\mathrm{a}}$ & & & 11 & 17 & 13 & 28 & 17 & 12 & 12 & 21 & 11 & 18 & 16 \\
\hline $\mathrm{H}_{\circ}$ & & & 0.067 & 0.655 & 0.552 & 0.690 & 0.520 & 0.800 & 0.571 & 0.433 & 0.345 & 0.800 & 0.543 \\
\hline $\mathrm{H}_{\mathrm{e}}$ & & & 0.882 & 0.898 & 0.825 & 0.951 & 0.913 & 0.857 & 0.885 & 0.914 & 0.856 & 0.915 & 0.889 \\
\hline $\mathrm{P}$ & & & 0.0000 & 0.0000 & 0.0000 & 0.0165 & 0.0000 & 0.1233 & 0.0000 & 0.0000 & 0.0000 & 0.0000 & \\
\hline Kendari & $\mathrm{Ke}$ & 28 & & & & & & & & & & & \\
\hline $\mathrm{N}_{\mathrm{a}}$ & & & 19 & 12 & 14 & 23 & 21 & 8 & 11 & 21 & 14 & 17 & 16 \\
\hline $\mathrm{H}_{\mathrm{o}}$ & & & 0.333 & 0.893 & 0.680 & 0.571 & 0.536 & 0.840 & 0.857 & 0.654 & 0.679 & 0.857 & 0.690 \\
\hline $\mathrm{H}_{\mathrm{e}}$ & & & 0.931 & 0.866 & 0.874 & 0.934 & 0.943 & 0.816 & 0.855 & 0.927 & 0.882 & 0.880 & 0.891 \\
\hline$P$ & & & 0.0000 & 0.0355 & 0.0000 & 0.0000 & 0.0000 & 0.6049 & 0.2767 & 0.0041 & 0.0000 & 0.5814 & \\
\hline Luwuk & Lu & 28 & & & & & & & & & & & \\
\hline $\mathrm{N}_{\mathrm{a}}$ & & & 11 & 14 & 19 & 18 & 16 & 11 & 14 & 19 & 13 & 16 & 15.1 \\
\hline $\mathrm{H}_{\mathrm{o}}$ & & & 0.214 & 0.704 & 0.538 & 0.357 & 0.240 & 0.679 & 0.821 & 0.750 & 0.680 & 0.815 & 0.580 \\
\hline $\mathrm{H}_{\mathrm{e}}$ & & & 0.880 & 0.897 & 0.914 & 0.908 & 0.894 & 0.865 & 0.879 & 0.908 & 0.845 & 0.901 & 0.889 \\
\hline$P$ & & & 0.0000 & 0.0143 & 0.0000 & 0.0000 & 0.0000 & 0.1790 & 0.4611 & 0.0122 & 0.0195 & 0.0040 & \\
\hline
\end{tabular}


Table 1. Continued

\begin{tabular}{|c|c|c|c|c|c|c|c|c|c|c|c|c|c|}
\hline \multirow[b]{2}{*}{ site } & \multirow[b]{2}{*}{ abbreviation } & \multirow{2}{*}{$n$} & \multicolumn{10}{|l|}{ locus } & \multirow{2}{*}{ mean } \\
\hline & & & TC1 & TC3 & TC5 & TC6 & TC8 & Tc059 & Tc074 & Tc092 & Tc160 & Tc161 & \\
\hline Togian Islands & TI & 63 & & & & & & & & & & & \\
\hline $\mathrm{N}_{\mathrm{a}}$ & & & 27 & 18 & 24 & 32 & 28 & 11 & 19 & 30 & 17 & 20 & 22.6 \\
\hline $\mathrm{H}_{\circ}$ & & & 0.538 & 0.726 & 0.695 & 0.435 & 0.500 & 0.762 & 0.754 & 0.635 & 0.444 & 0.903 & 0.639 \\
\hline $\mathrm{H}_{\mathrm{e}}$ & & & 0.945 & 0.910 & 0.939 & 0.948 & 0.950 & 0.865 & 0.853 & 0.920 & 0.895 & 0.903 & 0.913 \\
\hline$P$ & & & 0.0000 & 0.0009 & 0.0000 & 0.0000 & 0.0000 & 0.0000 & 0.0168 & 0.0000 & 0.0000 & 0.0007 & \\
\hline Manado & $\mathrm{Ma}$ & 10 & & & & & & & & & & & \\
\hline $\mathrm{N}_{\mathrm{a}}$ & & & 6 & 6 & 13 & 12 & 7 & 7 & 10 & 10 & 10 & 9 & 9 \\
\hline $\mathrm{H}_{\circ}$ & & & 0.125 & 0.500 & 0.800 & 0.300 & 0.429 & 0.800 & 0.889 & 0.444 & 0.800 & 0.900 & 0.599 \\
\hline $\mathrm{H}_{\mathrm{e}}$ & & & 0.820 & 0.800 & 0.905 & 0.895 & 0.786 & 0.825 & 0.877 & 0.858 & 0.845 & 0.855 & 0.847 \\
\hline$P$ & & & 0.0000 & 0.0160 & 0.1545 & 0.0000 & 0.0043 & 0.0061 & 0.2589 & 0.0000 & 0.2453 & 0.9079 & \\
\hline Sangalaki & Sa & 17 & & & & & & & & & & & \\
\hline $\mathrm{N}_{\mathrm{a}}$ & & & 10 & 12 & 15 & 19 & 16 & 8 & 10 & 19 & 10 & 12 & 13.1 \\
\hline $\mathrm{H}_{\circ}$ & & & 0.636 & 0.706 & 0.647 & 0.471 & 0.706 & 0.765 & 0.824 & 0.471 & 0.765 & 1.000 & 0.699 \\
\hline $\mathrm{H}_{\mathrm{e}}$ & & & 0.851 & 0.893 & 0.882 & 0.929 & 0.915 & 0.768 & 0.860 & 0.931 & 0.843 & 0.875 & 0.875 \\
\hline$P$ & & & 0.0293 & 0.0383 & 0.0000 & 0.0028 & 0.0164 & 0.6118 & 0.5317 & 0.0000 & 0.1332 & 0.5761 & \\
\hline Kota Kinabalu & KK & 23 & & & & & & & & & & & \\
\hline $\mathrm{N}_{a}$ & & & 7 & 13 & 13 & 23 & 3 & 9 & 12 & 18 & 10 & 15 & 12.3 \\
\hline $\mathrm{H}_{\mathrm{o}}$ & & & 0.100 & 0.636 & 0.762 & 0.762 & 0.333 & 0.778 & 0.762 & 0.400 & 0.800 & 0.818 & 0.615 \\
\hline $\mathrm{He}_{\mathrm{e}}$ & & & 0.805 & 0.896 & 0.848 & 0.940 & 0.611 & 0.795 & 0.838 & 0.921 & 0.840 & 0.914 & 0.841 \\
\hline $\mathrm{P}$ & & & 0.0000 & 0.0000 & 0.0008 & 0.0000 & 0.1981 & 0.3930 & 0.5337 & 0.0000 & 0.0150 & 0.0000 & \\
\hline Misool & $\mathrm{Mi}$ & 11 & & & & & & & & & & & \\
\hline $\mathrm{N}_{a}$ & & & 9 & 8 & 10 & 17 & 8 & 8 & 8 & 13 & 9 & 10 & 10 \\
\hline $\mathrm{H}_{\mathrm{o}}$ & & & 0.375 & 0.818 & 1.000 & 0.818 & 0.500 & 0.818 & 0.818 & 0.545 & 0.545 & 0.818 & 0.706 \\
\hline $\mathrm{H}_{\mathrm{e}}$ & & & 0.859 & 0.839 & 0.885 & 0.934 & 0.830 & 0.773 & 0.810 & 0.901 & 0.806 & 0.860 & 0.850 \\
\hline$P$ & & & 0.0000 & 0.0727 & 0.2876 & 0.0697 & 0.0085 & 0.9206 & 0.9792 & 0.0000 & 0.0517 & 0.2861 & \\
\hline Biak & $B k$ & 20 & & & & & & & & & & & \\
\hline $\mathrm{N}_{\mathrm{a}}$ & & & 12 & 11 & 18 & 19 & 2 & 8 & 12 & 20 & 9 & 13 & 12.4 \\
\hline $\mathrm{H}_{\mathrm{o}}$ & & & 0.111 & 0.450 & 0.950 & 0.350 & 0.000 & 0.750 & 0.500 & 0.700 & 0.600 & 0.650 & 0.506 \\
\hline $\mathrm{H}_{\mathrm{e}}$ & & & 0.887 & 0.860 & 0.925 & 0.935 & 0.500 & 0.850 & 0.850 & 0.935 & 0.808 & 0.883 & 0.843 \\
\hline P & & & 0.0000 & 0.0000 & 0.0007 & 0.0000 & 0.3336 & 0.0079 & 0.0000 & 0.0008 & 0.0274 & 0.0000 & \\
\hline
\end{tabular}

$n=$ number of individuals; $N_{a}=$ number of alleles; $H_{0}=$ observed heterozygosity; $H_{e}=$ expected heterozygosity; $P=P$-value for deviations from Hardy-Weinberg proportions (HWP; The values in bold, $\mathrm{P}<0.00052$, mean in these loci, the populations are departed from HWP).

\section{Data analysis}

The genetic indices, including the number of alleles $\left(\mathrm{N}_{\mathrm{a}}\right)$, the observed heterozygosity $\left(\mathrm{H}_{\mathrm{o}}\right)$ and expected heterozygosity $\left(\mathrm{H}_{\mathrm{e}}\right)$, for each population were calculated with the program GenAlEx (v. 6.41; Peakall \& Smouse 2006). Deviations from Hardy-Weinberg proportions (HWP) for each locus in each population as well as all populations and all loci were performed using the Markov chain randomization test (Guo \& Thompson 1992) to estimate the exact two-tailed P-values, as implemented in the program GENEPOP WEB (v. 4.0.10; Raymond \& Rousset 1995; Rousset 2008). The significance level was adjusted by applying the sequential Bonferroni correction (Rice 1989).

Population structure was examined in several ways. First, pairwise genetic differentiation index $\left(\mathrm{F}_{\mathrm{st}}\right)$ estimates were estimated to assess the magnitude of differentiation among sample sites. An unbiased estimate of the significance of the probability test was calculated by using ARLEQUIN (v. 3.5;
Excoffier \& Lischer 2010) with 1000 iterations. The significance of the pairwise comparisons was evaluated after a sequential Bonferroni adjustment of the significance level. Second, in order to directly compare the results from both marker systems, correlations among population pairwise $\mathrm{F}_{\mathrm{st}}$ values obtained from microsatellites and mtDNA were analysed using a Mantel test with 1000 permutations (negative $\mathrm{F}_{\text {st }}$ values were set to zero). Genetic structure among populations was investigated by conducting a Bayesian analysis with the software STRUCTURE (v. 2.3.1; Pritchard et al. 2000), testing for different numbers of clusters (K) in the data. The admixture model was used, with no allele frequencies correlated between populations and no prior information on population origin. The individuals were assigned to clusters, even to two or more clusters, if their genotypes indicated that they were admixed. The assignment settings were 200,000 iterations and the first 20,000 as burn-in. K-values ranged from 1 to 8 and each test was run three times. The Delta $\mathrm{K}$ method $(\Delta \mathrm{K}=\mathrm{m}(\mid \mathrm{L}(\mathrm{K}+1)-2 \mathrm{~L}$ 


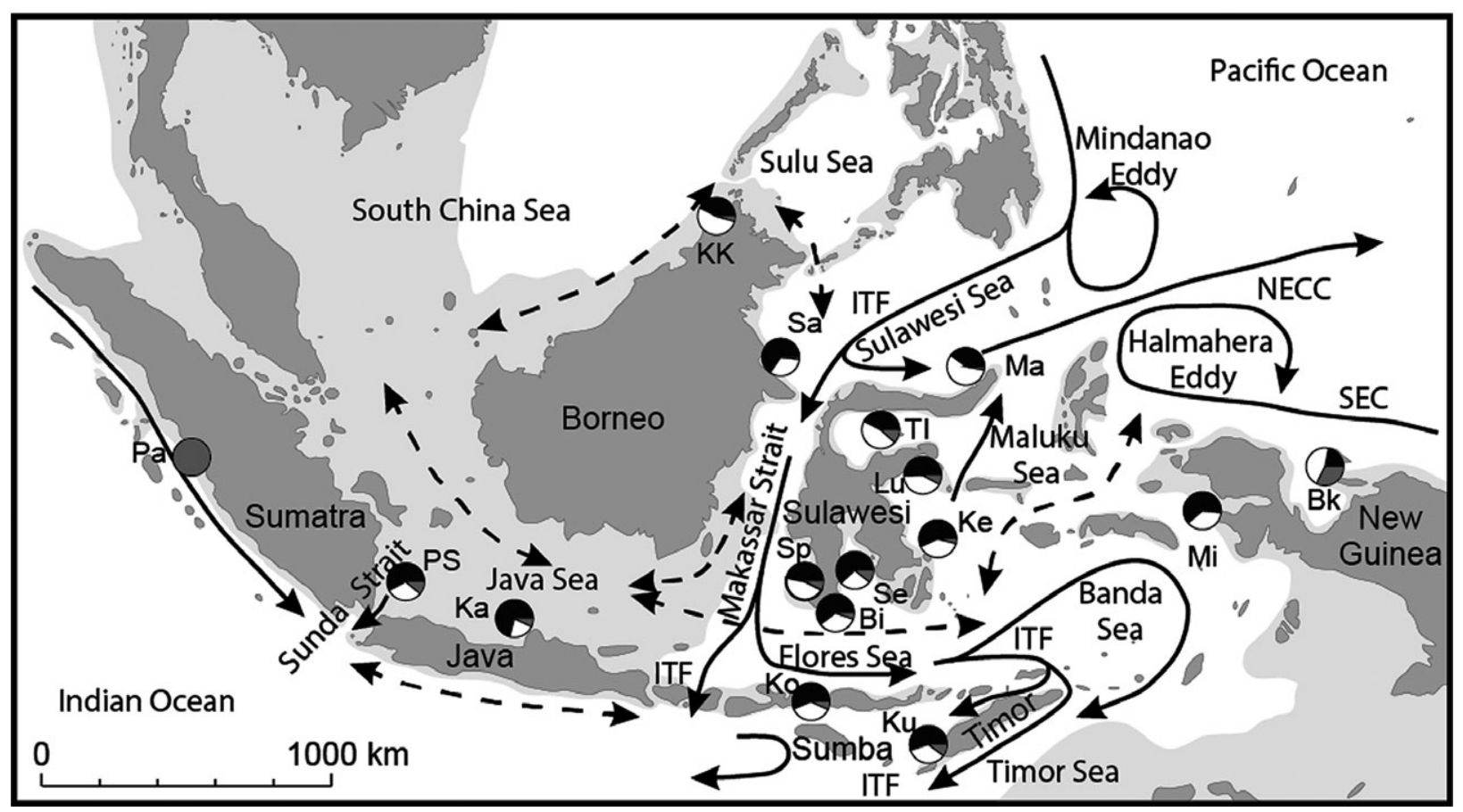

Fig. 1. Map of the Indo-Malay Archipelago with sample sites indicated (see Table 1 for definitions of abbreviations). Surface currents with dominant (solid lines) and seasonally changing currents (dashed lines) (Gordon 2005; Gordon \& Fine 1996; Wyrtki 1961), including the Indonesia Throughflow (ITF), South Equatorial Current (SEC) and North Equatorial Counter Current (NECC), are shown. The Pleistocene sea-level low stand of $120 \mathrm{~m}$ (light gray area) is also shown (Voris 2000). Pie charts represent the proportions of different genetic clusters (black, gray and white) in each population defined by STRUCTURE 2.3.1. See main text for explanations of the colours.

$(\mathrm{K})+\mathrm{L}(\mathrm{K}-1) \mid) / \mathrm{s}[\mathrm{L}(\mathrm{K})])$ was used to determine the exact $\mathrm{K}$ value (Evanno et al. 2005). Then all individuals were assigned to the most probable corresponding cluster and their frequencies were calculated for each population. These frequencies were drawn on a map as pie charts to visualize the distribution of the clusters. Third, an analysis of molecular variance (AMOVA) was conducted to find the spatial groups of populations that best explained the partitioning of genetic variance.

An isolation-by-distance (IBD) analysis was performed to test for a correlation between genetic distances $\left(\mathrm{F}_{\mathrm{st}}\right)$ and geographic distances by reduced major axis regression analysis. Later a Mantel test was conducted to check the significance of the correlation. All calculations were performed using the IBD web service (IBDWS 3.23, http://ibdws.sdsu.edu), applying 30,000 permutations (Jensen et al. 2005). Geographic distances were taken as the shortest way between two sample sites by sea, measured with an electronic world atlas (www.earthol.com).

\section{Results}

Genetic diversity of different populations

All 10 microsatellite loci showed high polymorphism. Across all loci, the mean number of alleles per population ranged from 4.0 (Padang, Pa) to 22.6 (Togian Islands) (Table 1). The high within-population diversity was also detected in the expected and observed heterozygosity values (Table 1). The population in Misool had the highest $\mathrm{H}_{\mathrm{o}}$ value (0.913), while the population from Biak, located in the West Pacific Ocean, showed the lowest (0.506).

In the HWP test, 94 observed genotype distributions generally conformed to HWP, but in 66 cases a significant deviation from HWP after adjustment of P-values with the sequential Bonferroni method was detected (Table 1). All global estimates of HWP for populations and loci showed significant heterozygote deficiency in each population and loci $(\mathrm{P}<0.0034)$.

Genetic population structure based on microsatellites and comparison with mtDNA

The overall AMOVA showed significant genetic structure $\left(\mathrm{F}_{\mathrm{st}}=0.023, \mathrm{P}<0.001\right)$. When a pairwise $\mathrm{F}_{\mathrm{st}}$ analysis $(\mathrm{P}<0.00054$ after sequential Bonferroni correction $)$ was performed, the population from the Eastern Indian Ocean (EIO; Pa), showed significant differentiation from all other populations $\left(\mathrm{F}_{\mathrm{st}}: 0.158-0.190\right)$, while the population from the Western Pacific (WP; Biak) also differed from most of the populations in the Central IMA $\left(\mathrm{F}_{\mathrm{st}}\right.$ : 
Table 2. Characteristics of microsatellite loci for Tridacna crocea.

\begin{tabular}{|c|c|c|c|c|c|}
\hline locus & primer sequence $\left(5^{\prime}-3^{\prime}\right)$ & $\mathrm{T}_{\mathrm{a}}\left({ }^{\circ} \mathrm{C}\right)$ & repeat motif & dye & expected size range (bp) \\
\hline TC1 & $\begin{array}{l}\text { F: GCTTTGTGGCTATTGGAGAA } \\
\text { R: GTCTGTCCCACCCGTCCATA }\end{array}$ & 56 & $(\mathrm{AG})_{22} \ldots(\mathrm{AG})_{16} \ldots(\mathrm{AG})_{6}$ & 6-FAM & 275-339 \\
\hline TC3 & $\begin{array}{l}\text { F: ACCATACCCCTGCCATACAGT } \\
\text { R: AGTCGCGTCACTCTGGATAG }\end{array}$ & 56 & $(A G)_{19}$ & HEX & $227-249$ \\
\hline TC5 & $\begin{array}{l}\text { F: AGAAATGACGTAACACCCAC } \\
\text { R: ATACTATGCAGAGGAAGGAG }\end{array}$ & 56 & $(\mathrm{CT})_{24}$ & 6-FAM & 135-165 \\
\hline TC6 & $\begin{array}{l}\text { F: CATGGTGGACGATGCCAAGT } \\
\text { R: CTACGAAAATCACTGACTCTG }\end{array}$ & 56 & $(A G)_{18}$ & 6-FAM & 160-206 \\
\hline TC8 & $\begin{array}{l}\text { F: CAAAGTTCAAAATACACTCG } \\
\text { R: TACCGTACCAGAGGCAACTA }\end{array}$ & 50 & $(\mathrm{ATGG})_{6} \ldots(\mathrm{ATGG})_{8} \ldots(\mathrm{ATGG})_{8}$ & HEX & $274-358$ \\
\hline Tc059 & $\begin{array}{l}\text { F: AGGTGACTTGAAGGTTAATGTTG } \\
\text { R: GGGTTTAAAACAACACGGTGA }\end{array}$ & 57.9 & $(A A C) 15$ & HEX & $110-140$ \\
\hline Tc074 & $\begin{array}{l}\text { F: CCAAAAACAGTCTTCCTTGACA } \\
\text { R: AGACTGCTCGCTGACCTTTT }\end{array}$ & 57.9 & $(\mathrm{AGTG}) 10$ & 6-FAM & $202-266$ \\
\hline Tc092 & $\begin{array}{l}\text { F: GCAACCCACTGAGTTCCCTA } \\
\text { R: TGCAGAGCGATAACATACAGG }\end{array}$ & 50 & (TC)13TTAA(AC)18 & HEX & $176-234$ \\
\hline Tc161 & $\begin{array}{l}\text { F: TGAAAATATGTTAACCCTCATCCTG } \\
\text { R: TTTGCAGACTGGTTTAGTCAACA }\end{array}$ & 57.9 & $(A C) 8$ & 6-FAM & $92-122$ \\
\hline
\end{tabular}

$\mathrm{F}=$ forward; 6-FAM, fluorescein amidite; $\mathrm{HEX}$, hexachloro fluorescein; $\mathrm{R}=$ reverse; $\mathrm{T}_{\mathrm{a}}=$ optimal annealing temperature.

Markers TC1, 3, 5, 6 and 8 were developed by Hui et al. (2011) and Tc059, 074, 092, 160 and 161 are from DeBoer \& Barber (2010).

Table 3. Pairwise genetic differentiation index $\left(\mathrm{F}_{\mathrm{st}}\right)$ values between populations of Tridacna crocea in the Indo-Malay Archipelago.

\begin{tabular}{|c|c|c|c|c|c|c|c|c|c|c|c|c|c|c|c|}
\hline sites & $\mathrm{Pa}$ & PS & $\mathrm{Ka}$ & Ko & $\mathrm{Ku}$ & $\mathrm{Sp}$ & $\mathrm{Bi}$ & $\mathrm{Se}$ & $\mathrm{Ke}$ & Lu & $\mathrm{TI}$ & Ma & Sa & KK & $\mathrm{Mi}$ \\
\hline PS & 0.165 & & & & & & & & & & & & & & \\
\hline $\mathrm{Ka}$ & 0.178 & 0.005 & & & & & & & & & & & & & \\
\hline Ko & 0.173 & 0.017 & 0.006 & & & & & & & & & & & & \\
\hline $\mathrm{Ku}$ & 0.190 & 0.017 & 0.023 & 0.006 & & & & & & & & & & & \\
\hline $\mathrm{Sp}$ & 0.158 & 0.009 & 0.013 & 0.007 & 0.007 & & & & & & & & & & \\
\hline $\mathrm{Bi}$ & 0.174 & 0.009 & 0.020 & -0.003 & -0.001 & 0.001 & & & & & & & & & \\
\hline Se & 0.162 & 0.023 & 0.014 & 0.009 & 0.020 & 0.010 & 0.006 & & & & & & & & \\
\hline $\mathrm{Ke}$ & 0.180 & 0.015 & 0.017 & 0.003 & 0.009 & 0.007 & 0.012 & 0.010 & & & & & & & \\
\hline Lu & 0.177 & 0.020 & 0.026 & 0.010 & 0.014 & 0.014 & 0.003 & 0.018 & 0.010 & & & & & & \\
\hline TI & 0.159 & 0.018 & 0.027 & 0.014 & 0.018 & 0.009 & 0.008 & 0.019 & 0.010 & 0.012 & & & & & \\
\hline $\mathrm{Ma}$ & 0.188 & 0.024 & 0.029 & 0.017 & 0.032 & 0.016 & 0.023 & 0.025 & 0.027 & 0.019 & 0.025 & & & & \\
\hline Sa & 0.174 & 0.014 & 0.009 & 0.007 & 0.003 & 0.005 & -0.008 & 0.009 & 0.010 & 0.014 & 0.014 & 0.023 & & & \\
\hline KK & 0.186 & 0.013 & 0.021 & 0.011 & 0.017 & 0.007 & 0.015 & 0.021 & 0.021 & 0.018 & 0.016 & 0.029 & 0.014 & & \\
\hline $\mathrm{Mi}$ & 0.186 & 0.018 & 0.028 & 0.009 & 0.019 & 0.014 & 0.002 & 0.018 & 0.017 & 0.020 & 0.021 & 0.033 & 0.004 & 0.010 & \\
\hline$B k$ & 0.161 & 0.039 & 0.048 & 0.042 & 0.048 & 0.036 & 0.030 & 0.040 & 0.041 & 0.038 & 0.029 & 0.039 & 0.035 & 0.039 & 0.043 \\
\hline
\end{tabular}

Values in bold mean populations are significantly differentiated after sequential Bonferroni correction with $\mathrm{P}<0.00054$.

See Table 1 for definitions of site name abbreviations.

0.029-0.048) (Table 3). In the Central IMA, the population in the Togian Islands was different from the populations in Karimunjava (Ka), Komodo, Spermonde and Sembilan Islands $(\mathrm{Se})\left(\mathrm{F}_{\mathrm{st}}: 0.009-0.027\right)$, while the other populations showed no significant difference between each other.

A Mantel test revealed a significant correlation of pairwise $\mathrm{F}_{\text {st }}$ values $(\mathrm{r}=0.946, \mathrm{P}<0.001)$ based on microsatellites (Table 3 ) and cytochrome c oxidase subunit I (COI) sequences, suggesting that the two data sets have a similar genetic population structure.

The cluster analysis with STRUCTURE revealed the presence of three rather distinct populations. The ancestry of each individual from the three inferred clusters was then calculated, and the cluster frequencies for each population are presented in Fig. 1. As shown, the dominant cluster in the EIO $(\mathrm{Pa})$ was gray and individuals were all assigned to this cluster. In the Central IMA [Java Sea, 
Table 4. Results of hierarchical analysis of molecular variance of microsatellite markers in Tridacna crocea from the Indo-Malay Archipelago.

\begin{tabular}{|c|c|c|}
\hline groupings & $\mathrm{F}_{\mathrm{ct}}$ & $\begin{array}{l}\text { percentage of } \\
\text { variation }(\%)\end{array}$ \\
\hline $\begin{array}{l}\text { (Pa) }(\mathrm{PS}, \mathrm{Ka}, \mathrm{Ko}, \mathrm{Ku}, \mathrm{Sp}, \mathrm{Bi}, \mathrm{Se}, \mathrm{Ke}, \mathrm{Lu}, \\
\mathrm{TI}, \mathrm{Ma}, \mathrm{Sa}, \mathrm{KK}, \mathrm{Mi})(\mathrm{Bk})\end{array}$ & $0.063^{*}$ & 6.27 \\
\hline $\begin{array}{l}\text { (Pa) (PS, Ka, Ko, Ku, Sp, Bi, Se, Ke, Lu, } \\
\mathrm{TI}, \mathrm{Ma}, \mathrm{Sa}, \mathrm{KK})(\mathrm{Mi}, \mathrm{Bk})\end{array}$ & $0.041 * *$ & 4.10 \\
\hline $\begin{array}{l}\text { (Pa) (PS, Ka, Ko, Ku, Sp, Bi, Se, Ke, Lu, } \\
\mathrm{Tl}, \mathrm{KK}, \mathrm{Mi})(\mathrm{Ma}, \mathrm{Sa})(\mathrm{Bk})\end{array}$ & $0.033 * *$ & 3.35 \\
\hline $\begin{array}{l}\text { (Pa) }(\mathrm{PS}, \mathrm{Ka}, \mathrm{Ko}, \mathrm{Ku}, \mathrm{Sp}, \mathrm{Bi}, \mathrm{Se}, \mathrm{Ke}, \mathrm{Lu}, \\
\mathrm{TI}, \mathrm{Ma}, \mathrm{Mi})(\mathrm{Sa}, \mathrm{KK})(\mathrm{Bk})\end{array}$ & $0.028 *$ & 2.82 \\
\hline $\begin{array}{l}(\mathrm{Pa})(\mathrm{PS}, \mathrm{Ka}, \mathrm{Ko}, \mathrm{Ku})(\mathrm{Sp}, \mathrm{Bi}, \mathrm{Se}, \mathrm{Ke} \\
\mathrm{Lu}, \mathrm{Tl}, \mathrm{Ma}, \mathrm{Sa}, \mathrm{KK}, \mathrm{Mi})(\mathrm{Bk})\end{array}$ & $0.023 * * *$ & 2.32 \\
\hline $\begin{array}{l}(\mathrm{Pa})(\mathrm{PS}, \mathrm{Ka})(\mathrm{Ko}, \mathrm{Ku}, \mathrm{Sp}, \mathrm{Bi}, \mathrm{Se}, \mathrm{Ke}, \\
\mathrm{Lu}, \mathrm{TI}, \mathrm{Ma}, \mathrm{Sa}, \mathrm{KK}, \mathrm{Mi})(\mathrm{Bk})\end{array}$ & $0.016 *$ & 1.60 \\
\hline
\end{tabular}

$*=0.05 \geq \mathrm{P} \geq 0.01 ; * *=0.01>\mathrm{P}>0.001 ; * * *=\mathrm{P}<0.001 ; \mathrm{F}_{\mathrm{ct}}$, genetic differences among groups.

See Table 1 for definitions of site name abbreviations.

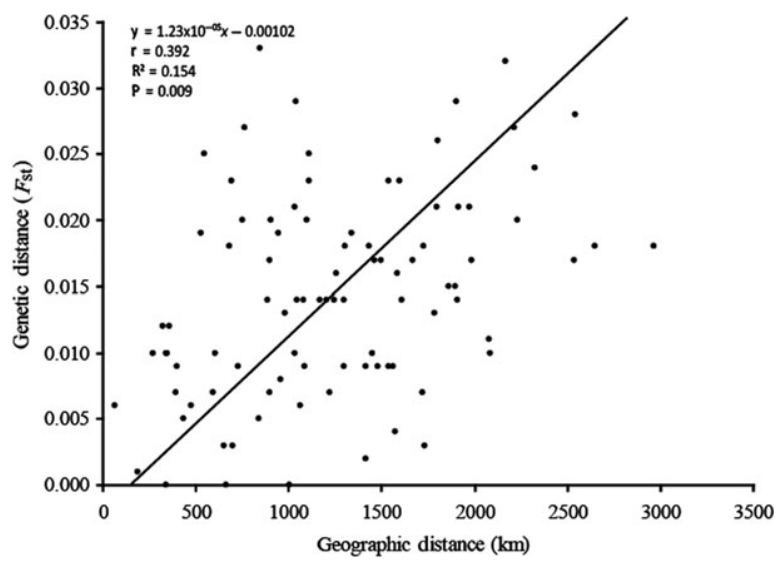

Fig. 2. Relationships between genetic and geographic distances for Tridacna crocea by reduced major axis regression without the populations from Padang and Biak.

South China Sea, Indonesian Throughflow (ITF), as well as seas to the east of Sulawesi], the dominant clusters were black and white, while in the WP (Biak), the dominant clusters were gray and white.

Based on geography and oceanography, a hierarchical AMOVA was carried out with different groupings (Table 4) for the 16 sample sites. The AMOVA revealed the highest fixation index $\left(\mathrm{F}_{\mathrm{ct}}=0.063, \mathrm{P}<0.05\right)$ and variation $(6.27 \%)$ among groups when the populations were grouped into the following regions: (i) EIO, (ii) Central IMA and (iii) WP. Compared with the results of the previous study based on COI (Kochzius \& Nuryanto 2008), the structure was highly similar. However, populations in the Java Sea [Ka, Pulau Seribu (PS)] were grouped into one separate cluster in the study using COI sequences (Kochzius \& Nuryanto 2008), while this divergence was not detected by microsatellites in the present study.

Isolation-by-distance showed a significant positive correlation between genetic $\left(\mathrm{F}_{\mathrm{st}}\right)$ and geographic distance in the Central IMA ( $\mathrm{r}=0.392, \mathrm{P}=0.009$ ) (Fig. 2). Divergent populations from Padang and Biak were excluded from this analysis. This correlation was also detected by the previous study based on COI $(\mathrm{r}=0.430, \mathrm{P}=0.004)$ (Kochzius \& Nuryanto 2008).

\section{Discussion}

The results based on 10 microsatellite loci were generally concordant with the results obtained using COI sequences, supporting the applicability of this mtDNA marker in connectivity studies for giant clams.

\section{Genetic diversity and HWP}

The genetic diversity in all populations based on microsatellites was very high, with the average $\mathrm{N}_{\mathrm{a}}$ ranging from 4 to 22.6. The $\mathrm{H}_{\mathrm{o}}$ values ranged from 0.506 to 0.706 . Similar results were found in the COI analysis, as illustrated by the high overall haplotype diversity (0.93). Molecular markers have also revealed high levels of genetic diversity in some other marine bivalves, such as Crassostrea plicatula and Crassostrea gigas (microsatellites; Yu et al. 2008), Chlamys farreri (microsatellites; Zhan et al. 2009) and Tridacna maxima (COI; Nuryanto \& Kochzius 2009). These findings may be due to the large population sizes and high nucleotide mutation rates in this taxon (Launey \& Hedgecock 2001; Hedgecock et al. 2004). Compared with other populations, the one in the EIO, i.e. population $\mathrm{Pa}$, showed a much lower genetic diversity than the others, possibly due to its small population size. Populations from the Java Sea (Ka, PS) showed the lowest genetic diversity in the COI analysis, possibly as a result of over-exploitation or the re-colonization of the Sunda Shelf as sea levels rose after the last glacial (Kochzius \& Nuryanto 2008). However, the genetic diversity levels detected by microsatellite markers were moderate in these two populations. This suggests that different markers might detect different levels of genetic diversity (Hoffman et al. 2009). Comparing mtDNA and nuDNA, the effective population size of mtDNA is much smaller than that of nuDNA (about a quarter, Avise 1994). Therefore, mtDNA might be more sensitive to genetic drift than nuDNA, which partly induced the difference of genetic diversity revealed by the two marker systems.

Global tests of HWP for populations and loci found significant heterozygote deficiency in all populations, possibly caused by inbreeding or population expansion. 
Further, significant departure from HWP in the form of heterozygote deficit may also be ascribed to a Wahlund effect caused by subpopulation structure. It could also be a consequence of the relationship between sample size and microsatellite variability: considering the high allele numbers in the different populations, HWP testing could have been influenced by small sample size (Györffy et al. 2004). However, the smallest population ( $\mathrm{Pa}$ ) showed no deviation from HWP.

\section{Genetic population structure}

Three distinct groups were found in the IMA based on the microsatellite analysis, corresponding to the (i) EIO, (ii) Central IMA and (iii) WP. This result was similar to previous studies using COI as a genetic marker and the study of DeBoer et al. (2014). However, in the study of Kochzius \& Nuryanto (2008), populations in the Java Sea were assigned to a separate group. In addition, the highly divergent mtDNA clades in the previous study (Kochzius \& Nuryanto 2008) suggested that there might be cryptic species, while the genetic structure revealed by microsatellites in this study was much lower. Given that Tridacna crocea is hermaphroditic, sex-biased gene flow in mtDNA cannot be the reason for this difference. One reason might be the homoplasy of microsatellite alleles. Alleles of the same size might have variation in the non-repeated flanking sequences (Grimaldi \& Crouau-Roy 1997), which might lead to underestimation of genetic differentiation. Again, random genetic drift due to severe bottlenecks, especially for mtDNA, which is more sensitive to effective population size changes, may have created divergent genetic groups during the sea-level fluctuations. Moreover, the higher mutation rate in microsatellite DNA (average $1.2 \times 10^{-3}$ per generation; Weber \& Wong 1993) compared with mtDNA could be another factor inducing the difference (Fauvelot et al. 2003; Timm et al. 2012). Therefore, claims of a generally higher resolving power for either marker type are not correct (Larsson et al. 2009). However, the pairwise $F_{s t}$ values based on microsatellite data obtained here are highly correlated with the values obtained from the COI data $(r=0.946$, $\mathrm{P}<0.001)$, which indicates that the two marker systems generally revealed concordant genetic structures. In the Central IMA, the results from microsatellites also revealed that the populations in this area showed high gene flow (low pairwise $\mathrm{F}_{\text {st }}$ values that were not significant). There was also a positive correlation between genetic and geographic distances, which was similar to the results revealed by mtDNA.

Similar genetic structures have been found in two other giant clam species (Tridacna maxima, Nuryanto \& Kochzius 2009; Tridacna squamosa, Hui et al. 2016). Vicariance due to Plio-Pleistocene sea-level fluctuation is suggested to have been a major force driving the genetic divergence between Indian and Pacific Ocean populations (e.g. Mcmillan \& Palumbi 1995; Williams \& Benzie 1998; Kochzius et al. 2003, 2009; Timm \& Kochzius 2008; Knittweis et al. 2009). The oceanography of the Indo-West Pacific, such as the ITF and Halmahera eddy (Fig. 1), and the somewhat limited larval dispersal capability are possible factors shaping the genetic structure and connectivity of giant clam populations.

Collectively, the concordant genetic structures illustrated by the two marker systems confirmed the reliability of the results presented here. Moreover, the mtDNA revealed much stronger population structure than the nuDNA, which may be because of the characteristics of mtDNA, such as lower effective population sizes and short coalescence times. The combination of mtDNA and nuDNA markers is expected to provide a more complete understanding of population genetics in future studies.

\section{Acknowledgements}

We would like to thank to the institutions and individuals that made our study possible: the German Federal Ministry of Education and Research (BMBF) (grant nos 03F0390B and 03F0472B), which funded this study in the framework of the Science for the Protection of Indonesian Coastal Marine Ecosystems (SPICE) project; China Scholarship Council (CSC) for the Ph.D. scholarship to Min Hui; Janne Timm (University of Bremen, Germany) for support during collection of samples; colleagues from Hasanuddin University (Indonesia) for logistical support during field work; and the relevant authorities for issuing permits. The SPICE project is conducted and permitted under a governmental agreement between the BMBF and the Indonesian Ministry for Research and Technology (RISTEK), Indonesian Institute of Sciences (LIPI), Indonesian Ministry of Maritime Affairs and Fisheries (DKP) and Indonesian Agency for the Assessment and Application of Technology (BPPT).

\section{References}

Avise J.C. (1994) Molecular Markers, Natural History, and Evolution. Chapman and Hall, New York: 511.

Avise J.C. (2000) Phylogeography: the History and Formation of Species. Harvard Univiversity Press, Cambridge: 447.

Barrowclough G.F., Zink R.M. (2009) Funds enough, and time: mtDNA, nuDNA and the discovery of divergence. Molecular Ecology, 18, 2934-2936.

Bazin E., Glémin S., Galtier N. (2006) Population size does not influence mitochondrial genetic diversity in animals. Science, 312, 570-572. 
Benzie J.A.H., Williams S.T. (1992a) Genetic structure of giant clam (Tridacna maxima) populations from reefs in the Western Coral Sea. Coral Reefs, 11, 135-141.

Benzie J.A.H., Williams S.T. (1992b) No genetic differentiation of giant clams (Tridacna gigas) populations in the Great Barrier Reef, Australia. Marine Biology, 112, 1-5.

Benzie J.A.H., Williams S.T. (1995) Gene flow among giant clam (Tridacna gigas) populations in Pacific does not parallel ocean circulation. Marine Biology, 123, 781-787.

Benzie J.A.H., Williams S.T. (1997) Genetic structure of giant clams (Tridacna maxima) populations in the west Pacific is not consist with dispersal by present-day ocean currents. Evolution, 51, 768-783.

Benzie J.A.H., Ballment E., Forbes A.T., Demetriades N.T., Sugama K., Haryanti, Moris S. (2002) Mitochondrial DNA variation in Indo-Pacific populations of the giant tiger prawn, Penaeus monodon. Molecular Ecology, 11, 2553-2569.

Brown W.M. (1985) The Mitochondrial Genome of Animals. Molecular Evolutionary Genetics, Plenum, New York: 95130.

Campbell C.A., Valentine J.W., Ayala F.J. (1975) High genetic variability in a population of Tridacna maxima from the Great Barrier Reef. Marine Biology, 33, 341-345.

Crandall E.D., Jones M.E., Muñoz M.M., Akinronbi B., Erdmann M.V., Barber P.H. (2008a) Comparative phylogeography of two seastars and their ectosymbionts within the Coral Triangle. Molecular Ecology, 17, 52765290.

Crandall E.D., Frey M.A., Grosberg R.K., Barber P.H. (2008b) Contrasting demographic history and phylogeographical patterns in two Indo-Pacific gastropods. Molecular Ecology, 17, 11-626.

DeBoer T.S., Barber P.H. (2010) Isolation and characterization of 9 polymorphic microsatellite markers for the endangered boring giant clam (Tridacna crocea) and cross-priming testing in three other tridacnid species. Conservation Genetics Resources, 2, 353-356.

DeBoer T.S., Subia M.D., Erdmann M.V., Kovitvongsa K., Barber P.H. (2008) Phylogeography and limited genetic connectivity in the endangered boring giant clam across the coral triangle. Conservation Biology, 22, 1255-1266.

DeBoer T.S., Naguit M.R.A., Erdmann M.V., Ablan-Lagman M.C.A., Carpenter K.E., Toha A.H.A., Barber P.H. (2014) Concordant phylogenetic patterns inferred from mitochondrial and microsatellite DNA in the giant clam Tridacna crocea. Bulletin of Marine Science, 90, 301-329.

DiBattista J.D., Rocha L.A., Craig M.T., Feldheim K.A., Bowen B.W. (2012) Phylogeography of two closely related IndoPacific Butterflyfishes reveals divergent evolutionary histories and discordant results from mtDNA and microsatellites. Journal of Heredity, 103, 617-629.

Edwards S.V., Bensch S. (2009) Looking forwards or looking backwards in avian phylogeography? A comment on Zink and Barrowclough 2008. Molecular Ecology, 18, 2930-2933.
Evanno G., Regnaut S., Goudet J. (2005) Detecting the number of clusters of individuals using the software STRUCTURE: a simulation study. Molecular Ecology, 14, 2611-2620.

Excoffier L., Lischer H.E.L. (2010) Arlequin suite ver. 3.5: a new series of programs to perform population genetics analyses under Linux and Windows. Molecular Ecology Resources, 10, 564-567.

Fauvelot C., Bernardi G., Planes S. (2003) Reductions in the mitochondrial DNA diversity of coral reef fish provide evidence of population bottlenecks resulting from Holocene sea level change. Evolution, 57, 1571-1583.

Gordon A.L. (2005) Oceanography of the Indonesia seas and their through. Oceanography, 8, 14-27.

Gordon A.L., Fine R.A. (1996) Pathways of water between the Pacific and Indian oceans in the Indonesian seas. Nature, 379, 146-149.

Grimaldi M.C., Crouau-Roy B. (1997) Microsatellite allelic homoplasy due to variable flanking sequences. Journal of Molecular Evolution, 44, 336-340.

Guo S.W., Thompson E.A. (1992) Performing the exact test of Hardy-Weinberg proportion for multiple alleles. Biometrics, 48, 361-372.

Györffy B., Kocsis I., Vasarhelyi B. (2004) Biallelic genotype distributions in papers published in Gut between 1998 and 2003: altered conclusions after recalculating the HardyWeinberg equilibrium. Gut, 53, 614-616.

Hedgecock D., Li G., Hubert S., Bucklin K., Ribes V. (2004) Widespread null alleles and poor cross-species amplification of microsatellite DNA loci cloned from the Pacific oyster, Crassostrea gigas. Journal of Shellfish Research, 23, 379-386.

Hoffman J., Dasmahapatra K., Amos W., Phillips C., Gelatt T.S., Bickham J.W. (2009) Contrasting patterns of genetic diversity at three different genetic markers in a marine mammal metapopulation. Molecular Ecology, 18, 2961-2978.

Hui M., Kochzius M., Leese F. (2011) Isolation and characterisation of nine microsatellite markers in the boring giant clam (Tridacna crocea) and cross-amplification in five other tridacnid species. Marine Biodiversity, 42, 1-3.

Hui M., Kraemer W.E., Seidel C., Nuryanto A., Joshi A., Kochzius M. (2016) Comparative genetic population structure of three endangered giant clams (Tridacnidae) throughout the Indo-West Pacific: implications for divergence, connectivity, and conservation. Journal of Molluscan Studies, doi:10.1093/mollus/eyw001.

Jensen J.L., Bohonak A.J., Kelley S.T. (2005) Isolation by distance web service. BMC Genetics, 6, 13.

Juinio-Meñez M.A., Magsino R.M., Ravago-Gotanco R., Yu E.T. (2003) Genetic structure of Linckia laevigata and Tridacna crocea populations in the Palawan shelf and shoal reefs. Marine Biology, 142, 717-726.

Kittiwattanawong K. (1997) Genetic structure of giant clams, Tridacna maxima in the Andaman Seam Thailand. 
Phuket Marine Biological Center Speial Publication, 17, 109-114.

Kittiwattanawong K., Nugranad J., Sriswat T. (2001) High genetic divergence of Tridacna squamosa living at the west and east coasts of Thailand. Phuket Marine Biological Center Special Publication, 25, 343-347.

Knittweis L., Krämer W.E., Timm J., Kochzius M. (2009) Genetic structure of Heliofungia actiniformis (Scleractinia: Fungiidae) populations in the Indo-Malay Archipelago: implications for live coral trade management efforts. Conservation Genetics, 10, 241-249.

Kochzius M., Nuryanto A. (2008) Strong genetic population structure in the boring giant clam Tridacna crocea across the Indo-Malay Archipelago: implications related to evolutionary processes and connectivity. Molecular Ecology, 17, 3775-3787.

Kochzius M., Söller R., Khalaf M.A., Blohm D. (2003) Molecular phylogeny of the lionfish genera Dendrochirus and Pterois (Scorpaenidae, Pteroinae) based on mitochondrial DNA sequences. Molecular Phylogenetics and Evolution, 28, 396-403.

Kochzius M., Seidel C., Hauschild J., Kirchhoff S., Mester P., Meyer-Wachsmuth I., Nuryanto A., Timm J. (2009) Genetic population structures of the blue starfish Linckia laevigata and its gastropod ectoparasite Thyca crystallina. Marine Ecology Progress Series, 396, 211-219.

Larsson L.C., Charlier J., Laikre L., Ryman N. (2009) Statistical power for detecting divergence - organelle versus nuclear markers. Conservation Genetics, 10, 1255-1264.

Launey S., Hedgecock D. (2001) High genetic load in the Pacific oyster Crassostrea gigas. Genetics, 159, 255-265.

Laurent V., Planes S., Salvat B. (2002) High variability of genetic pattern in giant clam (Tridacna maxima) populations within French Polynesia. Biological Journal of the Linnaean Society, 77, 221-231.

Lee J.Y., Edwards S.V. (2008) Divergence across Australia's Carpentarian barrier: statistical phylogeography of the redbacked fairy wren (Malurus melanocephalus). Evolution, 62, 3117-3134.

Lucas J. (1988) Giant clams: description, distribution and life history. Giant clams in Asia and the Pacific. ACIAR Monograph, 9, 21-33.

Macranas J.M., Ablan C.A., Pante M.J.R., Benzie J.A.H., Williams S.T.H. (1992) Genetic structure of giant clam (Tridacna derasa) populations from reefs in the IndoPacific. Marine Biology, 113, 231-238.

Mcmillan W.O., Palumbi S.R. (1995) Concordant evolutionary patterns among Indo-West Pacific butterflyfishes.

Proceedings of the Royal Society of London. Series B: Biological Sciences, 260, 229-236.

Nelson J.S., Hoddell R.J., Chou L.M., Chan W.K., Phang V.P.E. (2000) Phylogeographic structure of false clownfish, Amphiprion ocellaris, explained by sea level changes on the Sunda shelf. Marine Biology, 137, 727-736.
Nuryanto A., Kochzius M. (2009) Highly restricted gene flow and deep evolutionary lineages in the giant clam Tridacna maxima. Coral Reefs, 28, 607-619.

Peakall R., Smouse P.E. (2006) GENALEX 6: genetic analysis in Excel. Population genetic software for teaching and research. Molecular Ecology Notes, 6, 288-295.

Perrin C., Borsa P. (2001) Mitochondrial DNA analysis of the geographic structure of Indian scad mackerel in the IndoMalay archipelago. Journal of Fish Biology, 59, 1421-1426.

Pritchard J.K., Stephens M., Donnelly P. (2000) Inference of population structure using multilocus genotype data. Genetics, 155, 945-959.

Raymond M., Rousset F. (1995) GENEPOP (version 1.2): population genetics software for exact tests and ecumenicism. Journal of Heredity, 86, 248-249.

Rice W.R. (1989) Analyzing tables of statistical tests. Evolution, 43, 223-225.

Rousset F. (2008) Genepop'007: a complete reimplementation of the Genepop software for Windows and Linux. Molecular Ecology Resources, 8, 103-106.

Timm J., Kochzius M. (2008) Geological history and oceanography of the Indo-Malay Archipelago shape the population structure in the false clown anemonefish (Amphiprion ocellaris). Molecular Ecology, 17, 3999-4014.

Timm J., Planes S., Kochzius M. (2012) High similarity of genetic population structure in the false clown anemonefish (Amphiprion ocellaris) found in microsatellite and mitochondrial control region analysis. Conservation Genetics, 13, 693-706.

Toews D.P.L., Brelsford A. (2012) The biogeography of mitochondrial and nuclear discordance in animals. Molecular Ecology, 21, 3907-3930.

Voris H.K. (2000) Maps of Pleistocene sea levels in Southeast Asia: shorelines, river systems and time durations. Journal of Biogeography, 27, 1153-1167.

Walsh P.S., Metzger D.A., Higuchi R. (1991) Chelex 100 as a medium for simple extraction of DNA for PCR-based typing from forensic material. BioTechniques, 10, 506.

Weber J.L., Wong C. (1993) Mutation of short tandem repeats. Human Molecular Genetics, 2, 1123-1128.

Williams S., Benzie J. (1998) Evidence of a biogeographic break between populations of a high dispersal starfish: congruent regions within the Indo-West Pacific defined by color morphs, mtDNA, and allozyme data. Evolution, 52, 87-99.

Wyrtki K. (1961) Physical Oceanography of the Southeast Asian Waters. University of California, Scripps Institution of Oceanography.

You E.M., Chiu T.S., Liu K.F., Tassanakajon A., Klinbunga S., Triwitayakorn K., de la Peña L.D., Li Y., Yu H.T. (2008) Microsatellite and mitochondrial haplotype diversity reveals population differentiation in the tiger shrimp (Penaeus monodon) in the Indo-Pacific region. Animal Genetics, 39, 267-277. 
Yu E.T., Juinio-Meñez M.A., Monje V.D. (2000) Sequence variation in the ribosomal DNA internal transcribed spacer of Tridacna crocea. Marine Biotechnology, 2, 511516.

Yu H., Li Q., Yu R. (2008) Genetic differentiation between Zhe oyster Crassostrea plicatula and Pacific oyster Crassostrea gigas populations in China assessed by microsatellite analysis. Fisheries Science, 74, 88-97.
Zhan A., Hu J., Hu X., Zhou Z., Hui M., Wang S., Peng W., Wang M., Bao Z. (2009) Fine-scale population genetic structure of Zhikong scallop (Chlamys farreri): do local marine currents drive geographical differentiation? Marine Biotechnology, 11, 223-235.

Zink R.M., Barrowclough G. (2008) Mitochondrial DNA under siege in avian phylogeography. Molecular Ecology, 17, 2107-2121. 